\title{
WATER DEFICIT ON GROWTH AND PHYSIOLOGICAL INDICATORS OF Bidens pilosa L. AND Bidens subalternans DC. ${ }^{1}$
}

\author{
MÁRCIO ALEXANDRE MOREIRA DE FREITAS², HAMURÁBI ANIZIO LINS²*, MATHEUS DE FREITAS SOUZA², \\ GABRIELLA DAIER OLIVEIRA PESSOA CARNEIRO², VANDER MENDONÇA², DANIEL VALADÃO SILVA²
}

\begin{abstract}
Stress caused by soil water deficit has been one of the main factors that inhibit plant growth. The knowledge of the factors related to the behavior of weed species under water stress conditions can contribute to the elaboration of effective control strategies. Two experiments were carried out to evaluate the effects of the degree and duration of water deficit on physiological and growth indicators of two weed species (Bidens pilosa L. and Bidens subalternans DC.). The stress degree was simulated by four soil moisture: 100, $75,50,25 \%$ of total soil capacity. The water deficit duration was evaluated by five intervals of water supply: 0 , $1,2,3,4,5$, and 6 days. The experiments were carried out in a randomized complete block design with six replicates. The evaluated variables were: the photosynthetic rate $\left(\mathrm{A} ; \mu \mathrm{mol} \mathrm{CO}_{2} \mathrm{~m}^{-2}\right)$, stomatal conductance (gs; $\mu \mathrm{mol} \mathrm{H}_{2} \mathrm{O} \mathrm{m}^{-2} \mathrm{~s}^{-1}$ ), transpiration (E; mmol $\mathrm{H}_{2} \mathrm{O} \mathrm{m}^{-2} \mathrm{~s}^{-1}$ ), number of leaves per plant, and dry matter of the roots, stems, leaves, and total. The results showed that the species of B. pilosa and B. subalternans tolerate low water availability conditions. Low stomatal opening and loss of leaves are mechanisms that ensure the survival of Bidens plants to the water deficit. However, water stress close to $25 \%$ of field capacity caused the death of species. The B. subalternans had higher sensitivity to the water deficit, showing a lower dry matter of leaf, stem, and root than B. pilosa.
\end{abstract}

Keywords: Weed. Abiotic stress. Beggarticks.

\section{DÉFICIT HÍDRICO SOBRE INDICADORES DE CRESCIMENTO E FISIOLÓGICOS DE Bidens pilosa L. E Bidens subalternans DC.}

RESUMO - O estresse provocado pelo déficit de água no solo tem sido um dos principais fatores que prejudicam o crescimento das plantas. $\mathrm{O}$ entendimento dos fatores relacionados ao comportamento das plantas daninhas em condições de estresse hídrico pode contribuir para a elaboração de estratégias eficientes de manejo. Dois experimentos foram realizados para avaliar os efeitos e duração do estresse hídrico sobre indicadores fisiológicos e de crescimento de Bidens pilosa L. e Bidens subalternans DC. O grau de estresse foi realizado avaliando-se quatro níveis de capacidade de vaso: 100, 75, 50 e 25\%. A duração do estresse hídrico incluiu cinco tratamentos: $0,1,2,3,4,5$ e 6 dias de intervalo de irrigação. Os experimentos foram realizados em blocos casualizados, com seis repetições. Foram avaliadas a taxa fotossintética $\left(\mathrm{A} ; \mu \mathrm{mol} \mathrm{CO}_{2} \mathrm{~m}^{-2}\right)$, condutância estomática ( $\mathrm{gs} ; \mu \mathrm{mol} \mathrm{H}_{2} \mathrm{O} \mathrm{m}^{-2} \mathrm{~s}^{-1}$ ), transpiração $\left(\mathrm{E}\right.$; mmol $\mathrm{H}_{2} \mathrm{O} \mathrm{m}^{-2} \mathrm{~s}^{-1}$ ), número de folhas por plantas e matéria seca de raízes, caules, folhas e total. Os resultados demostraram que a B. pilosa e $B$. subalternans podem suportar condições de baixa disponibilidade hídrica no solo. Os mecanismos envolvidos para essa habilidade podem estar relacionados com a redução da abertura estomática e a perda de folhas pela planta. Porém, esses mecanismos poderão ocorrer apenas quando a disponibilidade hídrica no solo aproxima a valores de $25 \%$ da capacidade de campo. A B. subalternans teve maior sensibilidade a redução de água disponível do solo, demostrando uma maior redução na matéria seca de folha, caule e raiz comparado a $B$. pilosa.

Palavras-chave: Planta daninha. Estresse abiótico. Picão preto.

\footnotetext{
${ }^{*}$ Corresponding author

${ }^{1}$ Received for publication in 08/14/2020; accepted in 03/24/2021.

Paper extracted from the Master's Thesis of Agronomy/Fitotecnia of the first author.

${ }^{2}$ Department of Agronomic and Forest Sciences, Universidade Federal Rural do Semi-Árido, Mossoró, RN, Brazil; marciofreitas2288@gmail.com - ORCID: 0000-0002-3951-6544, hamurabi_a_@hotmail.com - ORCID: 0000-0002-4548-9108, matheus_mafs10@hotmail.com - ORCID: 0000-0002-5424-6028, gabrielladopc@unipam.edu.br - ORCID: 0000-0003-0354-732X, vander@ufersa.edu.br - ORCID: 0000-0001-5682-5341, daniel.valadao@ufersa.edu.br - ORCID: 0000-0003-0644-2849.
} 


\section{INTRODUCTION}

Weeds cause direct and indirect damage to human activities such as problems in urban environments, highways, railways, and rural areas. In agricultural fields, the weeds can interfere with the yield of crops. The economic losses in agriculture due to weed interference vary 30 to $40 \%$, but in some situations, the losses can reach $100 \%$ (LORENZI, 2008; SOUZA et al., 2020).

The degree of weed interference with crops depends on factors as weed community (species, density, and spatial distribution), crop (cultivar), management (spacing, planting density, planting system), and environment (climate, soil, availability of resources). In addition to density and spatial distribution, the ability to adapt to adverse environments is a feature that increases the importance of some weed species in agricultural fields (SILVA et al., 2011; RAFAIN et al., 2020). For example, weed species that survive stress conditions, either during a crop season or between two seasons, can gradually increase the density of the infestation over time.

The domain of the area with better-adapted species can intensify the degree of interference on the crops, causing more significant yield losses or reducing the quality of the final product. Therefore, knowing the biology, ecology, and survival capacity of weed species can allow the adoption of practices to reduce costs on weed control.

Among the stress conditions that occur in agricultural environments, the water deficit has been highlighted due to scarcity and irregularities of rainfall (ASFAW et al., 2018). This change in environmental conditions may select weed species adapted to water restriction. Some species have already demonstrated high germination capacity and survival due to lack of water in the soil (RAMESH et al., 2017). For example, the intermediate tolerance to high temperatures and water deficit has made the Piper aduncum a troublesome weed in Xishuangbanna, China (WEN et al., 2015). In contrast, other weed species do not tolerate water deficit conditions, and consequently, water limitation in the agrosystems may impair the establishment of some species (RAMESH et al., 2017).

The differences between plant capacity and water stress can vary even for species of the same genus. Centrosema molle and Catasetum macrocarpum are species belonging to a genus (Centrosema) with good adaptability to water restriction conditions. However, one study showed that $C$. macrocarpum was able to tolerate more severe water deficit conditions due to a better physiology mechanism to prevent water loss (GUENNI et al., 2017).

Two species of the genus Bidens, Bidens pilosa and Bidens subalternans, are easily confused in the field due to their very similar morphological characteristics. Easy dispersion and high seed production capacity allow both $B$. pilosa and $B$. subalternans to colonize cultivated and noncultivated areas (PAMPLONA et al., 2020). In addition, these species have a great capacity to extract water and nutrients from the soil, making these species good competitors for growth resources, during various crop cycles (SANTOS et al., 2015; FREITAS et al., 2019; SOARES et al., 2019). According to Deiss et al. (2017), losses of productivity in the range of $30 \%$ in the soybean crop occurred due to the interference of $B$. pilos $a$ and $B$. subalternans.

The $B$. pilosa species has already been studied more in works involving their competitive capacity with some crops (LEMOS et al., 2013). A study has already shown that this species can absorb water under conditions of very low soil water potential (PROCÓPIO et al., 2004a). However, information about the $B$. subalternans is scarce in the literature.

Studies that address the behavior of $B$. pilosa and $B$. subalternans species in different environmental conditions are important to elucidate the ability of each species to colonize agricultural areas. Therefore, we hypothesized that the species $B$. pilosa and $B$. subalternans have different capacities to tolerate degrees and duration of water stress in the soil. The objective of this work was to evaluate the tolerance of the B. pilosa and B. subalternans species to the different degrees and duration of water stress in the soil.

\section{MATERIAL AND METHODS}

The experiments were carried out in a greenhouse at the Universidade Federal Rural do Semi-Árido, Mossoró, RN, from October to December 2016. The site has $5^{\circ} 11^{\prime}$ south latitude, $37^{\circ} 20^{\prime}$ longitude coordinates.

In the experiments, samples of a sandy loam clay soil were collected in an agricultural area with no herbicide application history in Mossoró, RN. The soil was air-dried, sieved in a $3 \mathrm{~mm}$ diameter mesh, and fertilized with $37.5,8.83$ and $37.5 \mathrm{~g} \mathrm{~m}^{-3}$ of $\mathrm{N}, \mathrm{P}_{2} \mathrm{O}_{5}$ and $\mathrm{K}_{2} \mathrm{O}$ respectively in each pot (CAVALCANTI, 2008). The granulometric and chemical analyses of the soil before fertilization are shown in Table 1. 
M. A. M. FREITAS et al.

Table 1. Granulometric and physico-chemical characteristics of the soil used in the experiment.

\begin{tabular}{|c|c|c|c|c|c|c|c|c|c|c|c|}
\hline \multicolumn{12}{|c|}{ Granulometric Analysis (dag kg ${ }^{-1}$ ) } \\
\hline Sand & & & & & & & & Textural & issifi & tion & \\
\hline \multicolumn{12}{|c|}{ Chemical analysis } \\
\hline $\mathrm{pH}$ & $\mathrm{Na}^{+}$ & $P$ & $\mathrm{~K}^{+}$ & $\mathrm{Ca}^{+}$ & $\mathrm{Mg}^{2+}$ & $\mathrm{Al}^{+3}$ & $\mathrm{H}+\mathrm{Al}^{+3}$ & CTC & $\mathrm{m}$ & $\mathrm{V}$ & $\mathrm{OM}$ \\
\hline$\left(\mathrm{H}_{2} \mathrm{O}\right)$ & \multicolumn{3}{|c|}{$\mathrm{mg} \mathrm{dm}^{-3}$} & \multicolumn{5}{|c|}{$\mathrm{cmol}_{\mathrm{c}} \mathrm{dm}^{-3}$} & \multicolumn{2}{|c|}{$\%$} & dag $\mathrm{kg}^{-1}$ \\
\hline 7.20 & 49.3 & 2.2 & 434.6 & 11.30 & 2.10 & 0.00 & 0.00 & 14.73 & 0 & 100 & 0.81 \\
\hline
\end{tabular}

The analyses carried out at the Soil Fertility and Plant Nutrition Laboratory of the Universidade Federal Rural do SemiÁrido, Mossoró, RN. pH: Hydrogenionic potential; OM: Organic matter.

Each pot was filled with $8 \mathrm{dm}^{-3}$ of dry soil and the level of soil moisture was determined by the method described by Steadman et al. (2004). The pots containing the dry soils were weighed, then watered to saturation, and covered with aluminum foil to minimize evaporation losses. The water was allowed to drain for a period of $36 \mathrm{~h}$, and reweighed to calculate the water content using the following equation:

$\mathrm{WC}=\left(\mathrm{W}_{\mathrm{w}}-\mathrm{W}_{\mathrm{d}}\right)$, at where:

$\mathrm{WC}$ is the water content in the vessel, $\mathrm{W}_{\mathrm{w}}$ is the wet weight of the vessel with soil, $\mathrm{W}_{\mathrm{d}}$ is the weight of the dry vessel with soil.

Two weed species used in the study were Bidens pilosa L. and Bidens subalternans DC. Seeds of $B$. pilosa L. and B. subalternans DC. were collected in the microregion of Mossoro, RN. The species were sown in trays of 128 cells and after 14 days were transplanted to plastic vessels with a volume capacity of $8 \mathrm{dm}^{-3}$, containing soil fertilizer.

Two experiments were carried out in a randomized complete block design, with six replicates. In the experiment on soil moisture levels (experiment 1), treatments were arranged in a $2 \times 4$ factorial scheme, and the factors were two species (B. pilosa and B. subalternans) and four soil moisture levels proportional to $100,75,50$, and $25 \%$ of field capacity.

In the stress duration experiment (experiment 2 ), the treatments were arranged in a $2 \times 5$ factorial scheme, with the factors corresponding to the two species ( $B$. pilosa and B. subalternans) and to the irrigation interval of $0,1,2,4$, and 6 days. In each treatment, a quantity of water was applied until it reached $100 \%$ of the field capacity. The irrigations were performed daily, keeping the humidity close to the field capacity $(70-80 \%)$. The soil moisture values in the field capacity (FC) and permanent wilt point (PWP) were 0.345 and $0.113 \mathrm{~cm}^{3} \mathrm{~cm}^{-3}$, resulting in a total storage (TS) of $0.232 \mathrm{~cm}^{3} \mathrm{~cm}^{-3}$.

In both experiments, the treatments were implemented at 10 days and finished at 45 days after transplanting, at which time the plants showed full flowering and the appearance of the first mature seeds. The average total water depth applied was equivalent to $154.2 \mathrm{~mm}$ in irrigated treatments (experiment 1), and $93.8 \mathrm{~mm}$ in treatments submitted to temporary deficit (experiment 2). The climatic conditions in the greenhouse were kept constant (maximum temperature $=35 \pm 2{ }^{\circ} \mathrm{C}$; average temperature $=28 \pm 2{ }^{\circ} \mathrm{C}$, minimum temperature $=$ $20 \pm 2{ }^{\circ} \mathrm{C}$; and relative humidity $=65 \pm 5 \%$ ).

At 45 days after transplanting, the photosynthetic rate $\left(\mathrm{A} ; \mu \mathrm{mol} \mathrm{CO}_{2} \mathrm{~m}^{-2}\right)$, stomatal conductance (gs; $\mu \mathrm{mol} \mathrm{H}_{2} \mathrm{O} \mathrm{m}^{-2} \mathrm{~s}^{-1}$ ), and transpiration were evaluated in young leaves of both Bidens species $\left(\mathrm{E} ; \mathrm{mmol} \mathrm{H}_{2} \mathrm{O} \mathrm{m} \mathrm{m}^{-2} \mathrm{~s}^{-1}\right)$ with the aid of an infrared gas analyzer LI-6400 (LI-COR Biosciences $\left.^{\mathbb{B}}\right)$. The readings were taken between 8 and $10 \mathrm{am}$. The $\mathrm{CO}_{2}$ contents were set at $400 \mu \mathrm{mols} \mathrm{m}^{-2} \mathrm{~s}^{-1}$ and the luminous intensity at $1500 \mu$ mols of photons $\mathrm{m}^{-2} \mathrm{~s}^{-1}$. The evaluations were made on young leaves, newly expanded, undamaged and well lit (when the light intensity was greater than $1000 \mu$ mols of photons $\mathrm{m}^{-2} \mathrm{~s}^{-1}$ ).

At the end of the experiment the plants were harvested and the height, number of leaves per plant, and dry matter were determined. To determine the dry biomass of the species, all plant material was collected, separating root and hoots, which were subsequently submitted to drying in a forced air circulation oven at $70 \pm 2{ }^{\circ} \mathrm{C}$ until reaching the constant dry mass. Measurements were given by the dry weight of each part on a precision scale.

The data were submitted to the Shapiro-Wilk residual normality test. To test homoscedasticity, the Bartlett test was performed, which is considered to be sensitive to the normality hypothesis. The data were submitted to analysis of variance by the $\mathrm{F}$ test at $p>0.05$. The averages were compared by the Tukey test at $p>0.05$. All statistical analyzes were performed using the SISVAR ${ }^{\circledR}$ software version 5.6. The graphics were made using the SigmaPlot ${ }^{\circledR} 12.0$ software. 


\section{RESULTS AND DISCUSSION}

\section{Experiment 1}

The plants of Bidens pilosa and Bidens subalternans demonstrated less stomatal conductance, transpiratory rate, and photosynthetic rate under conditions of $25 \%$ of field capacity in comparison to the other water contents (Figure 1). The lower stomatal conductance is a result of the lower stomate opening under water deficit conditions. In general, plants under low water availability in the soil close the stomata to avoid loss of water and to maintain the turgescence in their tissues (NEGIN; MOSHELION, 2016). This mechanism was observed for both species.
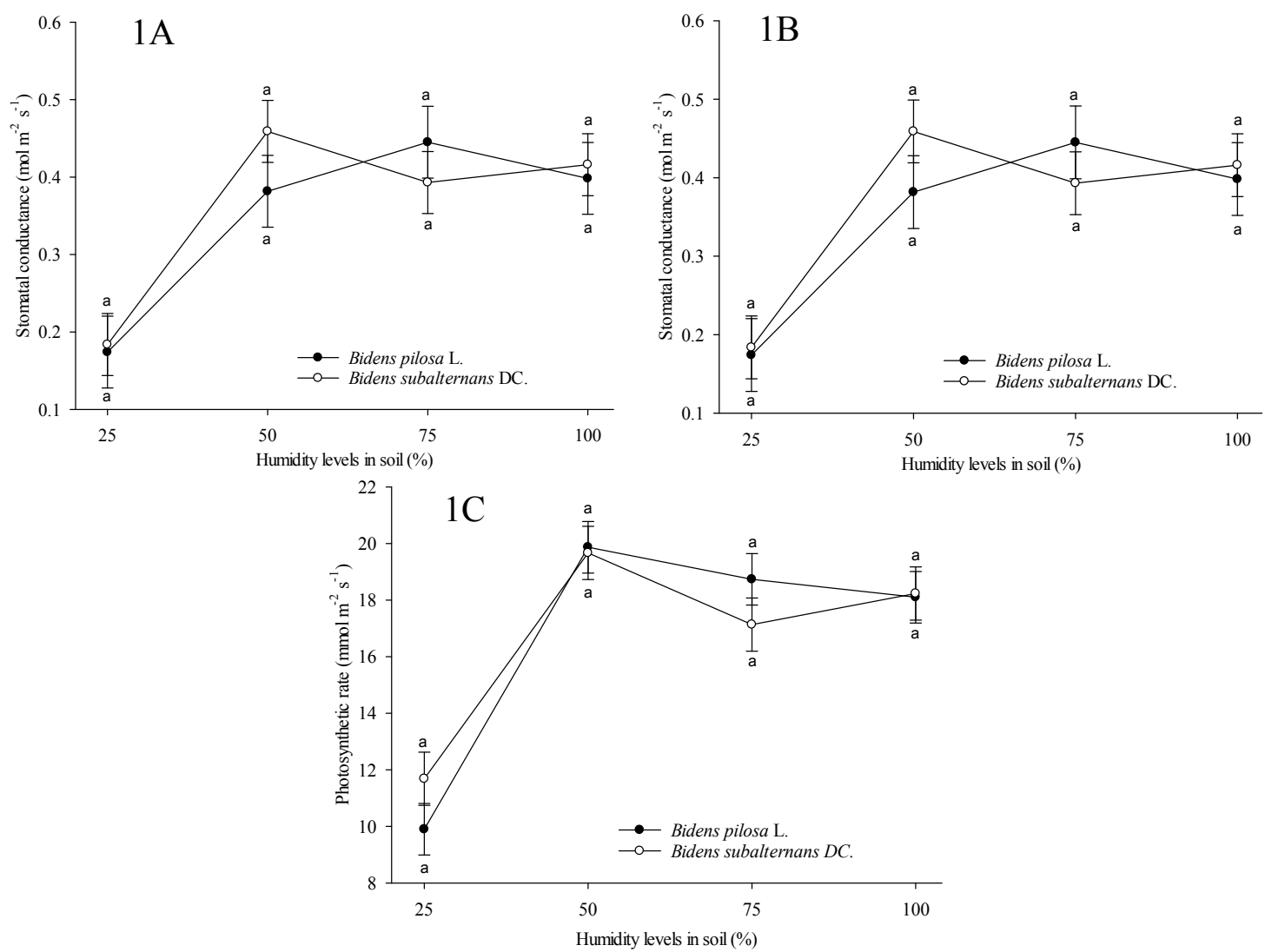

Figure 1. Stomatal conductance (gs), transpiration rate (E), and photosynthetic rate (A) of Bidens pilosa and Bidens subalternans at 45 days after transplanting and under different levels of soil moisture. Bars differ the effect of the water deficit in each species by the Tukey test at $p>0.05$. Letters differ the species in each treatment by the Tukey test at $p>0.05$.

The stomatal closure reduced the water loss through the stomata in both species, explaining the lower transpiration rate observed for the species under conditions of $25 \%$ of field capacity. The lower water loss in the stomata allows Bidens ssp. survival in water scarcity conditions. However, this watersaving mechanism via stomatal closure can impair plant photosynthesis, limiting the growth of plants (NEGIN; MOSHELION, 2016; MUDO et al., 2020).

B. pilosa demonstrate has a $60 \%$ reduction in the photosynthetic rate, whereas this value was $40 \%$ for B. subalternans (Figure 1C). The lowest photosynthetic rate of the two species was possibly caused by stomatal closure under conditions of $25 \%$ of field capacity. The lower opening of the stomata reduces the gas exchange, impairing the absorption of atmospheric $\mathrm{CO}_{2}$ into leaves. In $\mathrm{C} 3$ plants, such as
B. pilosa and B. subalternans, the reduction in internal carbon concentrations reduces the carboxylation of the Rubisco enzyme, decreasing carbon fixation (LLUSIA et al., 2016).

The plants of B. pilosa and B. subalternans presented similar values for stomatal conductance (mean of $0.42 \mathrm{~mol} \mathrm{~m} \mathrm{~m}^{-2} \mathrm{~s}^{-1}$ ) when they were maintained at 50, 75, and $100 \%$ soil moisture (Figure 1A). In the same conditions of field capacity, there was no difference for the transpiratory rate (mean of $5.8 \mathrm{mmol} \mathrm{H}_{2} \mathrm{O} \mathrm{m} \mathrm{m}^{-2} \mathrm{~s}^{-1}$ ) and photosynthetic rate (general mean of $18.3 \mu \mathrm{mol} \mathrm{CO}_{2} \mathrm{~m}^{-2} \mathrm{~s}^{-1}$ ) (Figures 1B, 1C). The plants can be classified as anisohydric and isohydric according to their behavior in conditions of water scarcity (NEGIN; MOSHELION, 2016). Anisohydric plants can maintain the stomatal opening even under conditions 
of lower water availability, and only under high water deficit conditions, the stomatal closure is observed. This mechanism allows the plant to reach a lower water potential in the leaf, increasing the water extraction capacity in the soil (NEGIN; MOSHELION, 2016). The B. pilosa and $B$. subalternans species demonstrated this ability since the stomatal closure was only detected in the condition of several hydric deficit $(25 \%$ of the water capacity).

A study that evaluated the water potential of the soil at the permanent wilting for B. pilosa, found that this condition was only reached close to $-1000 \mathrm{kPa}$, a value far below the values observed for other species $(-300 \mathrm{kPa})$ also evaluated, such as Phaseolus vulgaris, E. heterophylla, Glycine max, and Desmodium tortuosum (PROCÓPIO et al., 2004b). This result completes the hypothesis that the genus Bidens has an anisohydric behavior, which increases the capacity of the plant to extract water from the soil.

The number of leaves per plant was lower only under conditions of $25 \%$ of vessel capacity (Figure 2A). In addition to the stomatal closure, the loss of leaves can work as a mechanism that reduces water loss. Severe water restriction promoted the stomatal closure of Bidens species, and according to some authors, this mechanism is controlled by ABA levels in leaf tissue (SPINELLI et al., 2016). In addition to the stomatal closure, plants under conditions of severe water stress can raise the internal concentrations of $\mathrm{ABA}$, inducing foliar senescence. Although leaf senescence reduces the amount of photoassimilates produced, this mechanism can guarantee the plants of Bidens a greater tolerance to lack of water (NEGIN; MOSHELION, 2016).
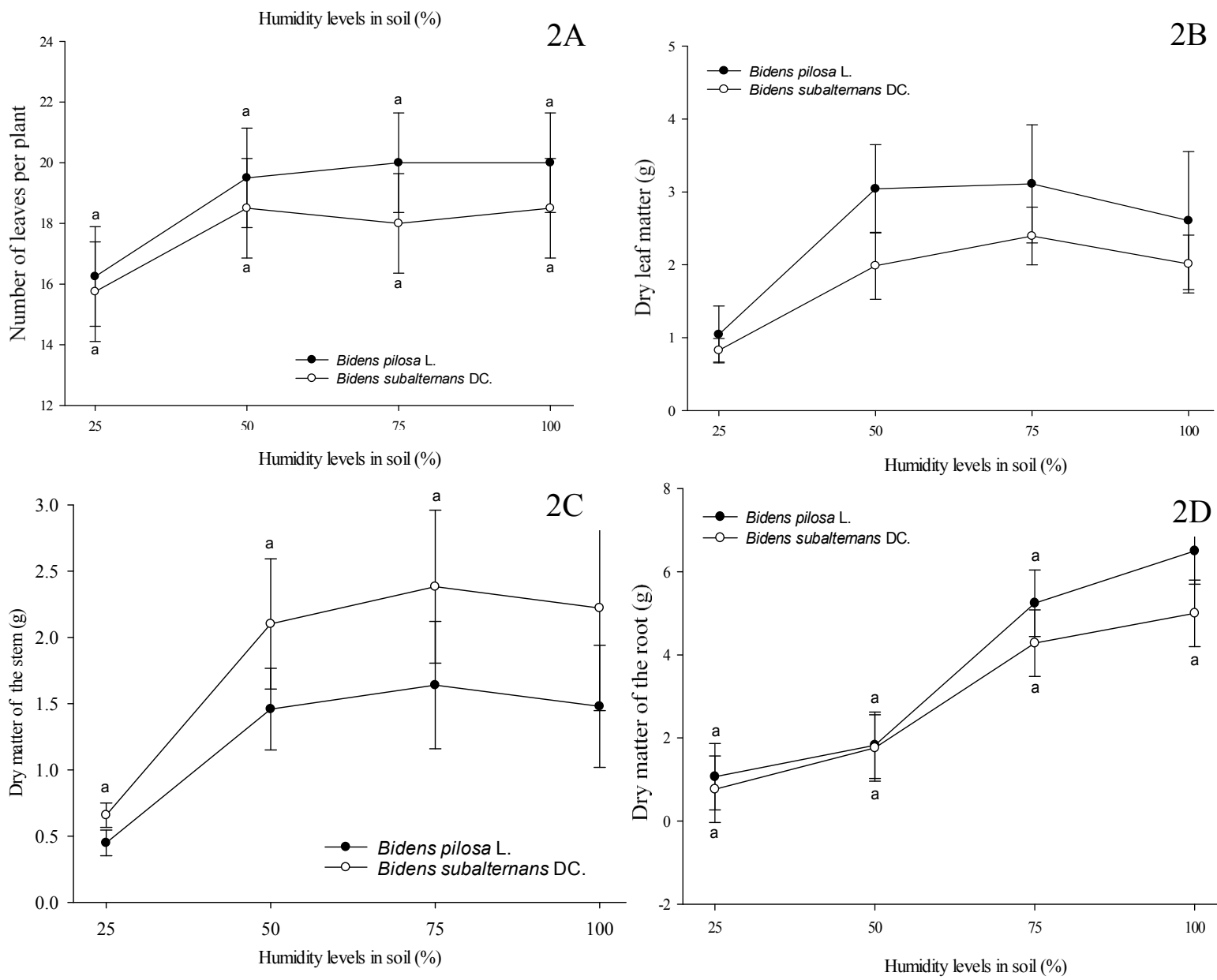

Figure 2. Number of leaves per plant, dry leaf matter, dry matter of the stem, and dry matter of the root of Bidens pilosa and Bidens subalternans at 45 days after transplanting and under different levels of soil moisture. Bars differ the effect of the water deficit in each species by the Tukey test at $p>0.05$. Letters differ the species in each treatment by the Tukey test at $p>0.05$. 
Leaf and stem dry matters were reduced for both species when the plants were submitted to conditions of $25 \%$ of vessel capacity (Figure 2B, $2 \mathrm{C})$. The lower dry matter in this condition may be the result of the lower photosynthetic rate of the plants caused by the stomatal closure. The low photosynthetic rate and the lower number of leaves per plant in Bidens species under severe stress conditions can reduce the amount of photoassimilates produced, reducing the accumulation of dry matter in different plant tissues (TOMBESI et al., 2015).

The root dry matter for both species reduced by $90 \%$ when submitted to $50 \%$ of the field capacity (Figure 2D). The increase in deficit to $25 \%$ of vessel capacity did not differ from treatment at $50 \%$ of vessel capacity (Figure 2D). The water deficit can stimulate the root growth of some plant species, increasing the volume of soil explored (TOMBESI et al., 2015). However, this effect was not observed for Bidens species. Some species may accumulate sugars of greater solubility in the roots, reducing their water potential (NEGIN; MOSHELION, 2016). Although reducing the accumulated dry matter in the tissues, this fact can increase the capacity of the plant in extracting water from the soil. This mechanism may be responsible for the greater tolerance of species of $B$. pilosa and $B$. subalternans to water deficit conditions.

\section{Experiment 2}

For the Exp 2 experiment, the photosynthetic activity of the species studied had similar behavior to that observed for stomatal conductance and transpiration (Figure 3). The reduction of photosynthesis may be related to factors regulating the stomatal activity of plants. Plants daily irrigated demonstrated a lower photosynthetic rate than plants with some water stress. An increase of approximately 20 to $30 \%$ of the photosynthetic rate of the B. subalternans and $B$. pilosa species, respectively, was observed when irrigated at intervals of 6 days in relation to those irrigated daily.
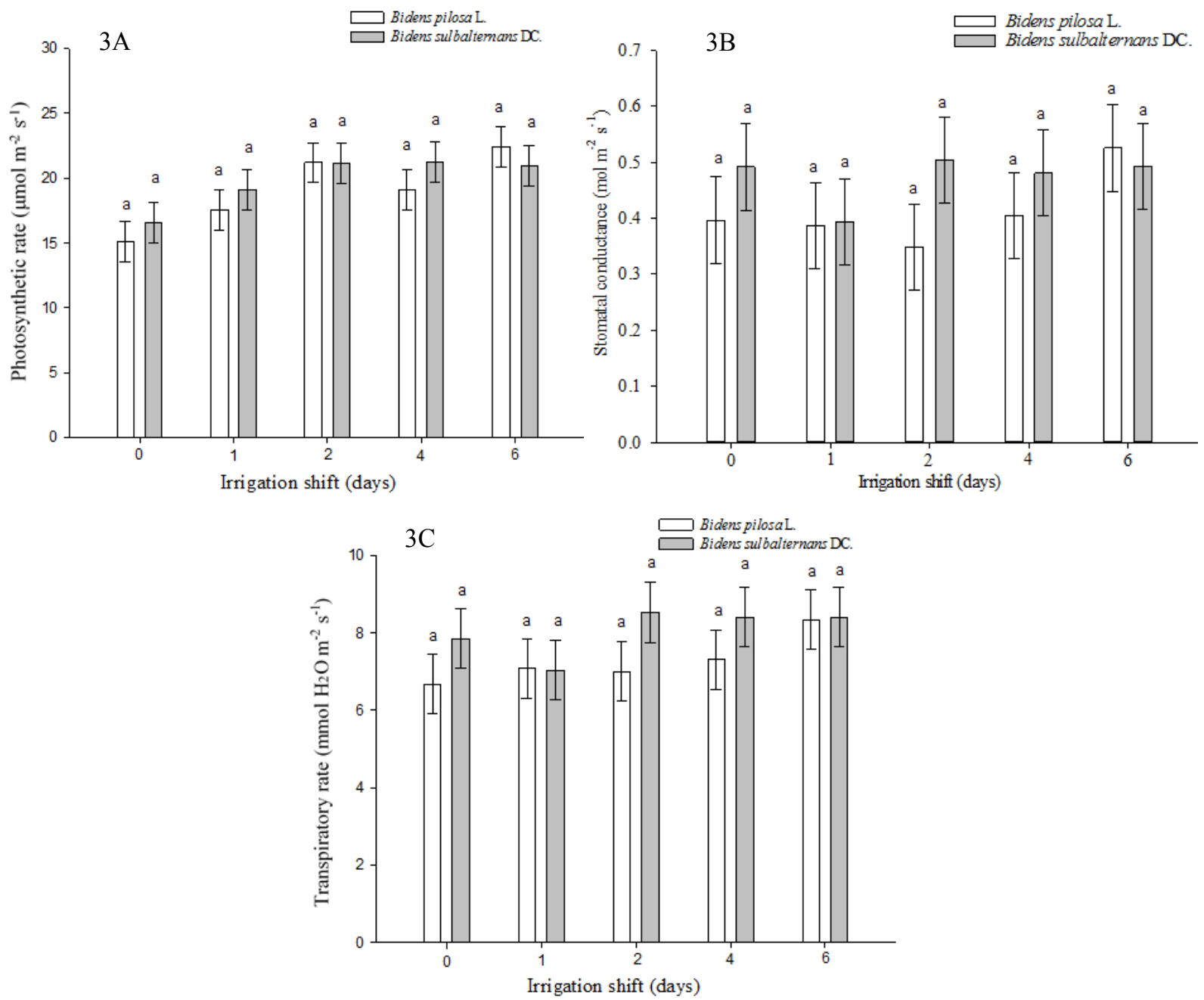

Figure 3. Photosynthetic rate (A), stomatal conductance (gs), and transpiratory rate (E) of Bidens pilosa and Bidens subalternans at 45 days after transplanting and under different irrigation periods. Bars differ the effect of the water deficit in each species by the Tukey test at $p>0.05$. Letters differ the species in each treatment by the Tukey test at $p>0.05$. 
The stomatal conductance (gs) values for studies with duration of water stress are shown in Figure 3B. For B. subalternans plants, mean values of gs close to $0.5 \mathrm{~mol} \mathrm{~m}^{-2} \mathrm{~s}^{-1}$ were observed, whereas in B. pilosa species they varied from $0.26 \mathrm{~mol} \mathrm{~m}^{-2} \mathrm{~s}^{-1}$ with irrigation at every two days up to $0.58 \mathrm{mmol}$ $\mathrm{H}_{2} \mathrm{O} \mathrm{m} \mathrm{m}^{-2} \mathrm{~s}^{-1}$ with a six-day interval between each irrigation, representing an approximately $100 \%$ increase in stomatal conductance. B. pilosa plants showed a reduction of $33 \%$ of $g s$ when irrigated daily in relation to those irrigated every 6 days (Figure 3B).

The behavior of the transpiration results (E) for Exp 2 for both species was similar to those of stomatal conductance and photosynthesis. The increase in the interval between irrigations, consequently water deficit, promoted a higher transpiratory rate mainly in $B$. pilosa plants, with an increase of approximately $30 \%$ in transpiration when the plants were irrigated every six days in relation to those irrigated daily (Figure 3C).

Freitas et al. (2020) observed a reduction in the transpiratory rate of $B$. pilos $a$ after the fifth day of water deficit. However, the same authors did not find any difference in the transpiration of Urochloa decumbens when subjected to 5 days of water stress.

The plants of $B$. pilosa present adaptation in response to the water deficit since in their initial phase of growth they tend to direct the photoassimilates to the development of the root system, which allows greater exploration of the soil in search of water (PROCÓPIO et al., 2002). This fact makes this weed highly competitive by water with crops of human interest when exposed to water stress conditions.

The reduction in stomatal conductance may occur due to the increase in leaf vapor pressure deficit, reduction of leaf water potential, and the effect of irradiance (LIMA et al., 2016). The reduction of the stomatal conductance happens to reduce the water loss of the plants due to the reduction of the available water in the soil. Although this reduction in the rate of water loss represents an immediate advantage to prevent tissue dehydration, it can directly influence the sensible heat balance of the plant and the absorption of $\mathrm{CO}_{2}$ and consequently the photosynthetic rate (OTTO et al., 2013). Therefore, the reduction in water availability causes a decrease in the water potential in the leaves of plants, resulting in loss of turgescence and reduction of stomatal conductance. Therefore, stomatal closure must have been the primary cause of the decrease in the transpiratory and photosynthetic rate under conditions of water deficit, since this reduction causes a decrease in $\mathrm{CO}_{2}$ availability in the sub-static chambers (FREITAS et al., 2020).

The reduction of stomatal conductance causes lower transpiration and, consequently, lower water loss, causing higher plant tolerance to water stress (DUTRA et al., 2015). This mechanism is an essential defense strategy, especially in semi-arid regions, where long periods occur without the occurrence of high-temperature rains (FREITAS et al., 2017; FREITAS et al., 2019).

Carvalho, Martins and Moreira (2012) observed a decrease in stomatal conductance in Hyptis pectinata when submitted to water deficit. Procópio et al. (2004b), evaluated the stomatal conductance of Euphorbia heterophylla, B. pilosa, and Desmodium tortuosum, finding values similar to those of B. pilosa and B. subalternans in the present study, with values ranging from 0.39 to $0.58 \mathrm{~mol} \mathrm{~m}^{-2} \mathrm{~s}^{-1}$, in the same period of water deficit.

These results show that the effect of the water deficit caused a reduction in the transpiration rate, due to the reduction of the water potential in the leaf, where the reduction of this potential caused the closure of the stomata, decreasing the stomatal conductance and consequently the decrease in the transpiration rate. Moreover, in a state of drought stress, the guiding cells perceive this scarcity of water in the mesophyll, even before any diminution of their turgidity occurs, and the stomata close, possibly due to the interference of abscisic acid (TAIZ et al., 2017).

Increasing the interval between irrigations and, consequently, water deficit, reduced stem (MSC), root (MSR), and total (MST) dry matter accumulation, as well as the number of leaves per plant of both species (Figure 4). The reduction of leaf numbers per plant was possibly caused by leaf fall as a strategy for plant survival to reduce water loss through transpiration and to increase the efficiency of water use in response to water stress (CECHIN et al, 2010).

The weed species $U$. decumbens and B. pilosa behaved differently after the imposition of water restriction. The physiological adaptations of each species can allow them to survive in conditions of water deficit. B. pilosa showed greater resistance to adverse conditions caused by water deficiency in relation to $U$. decumbens. Therefore, these results demonstrate the need to adopt cultural practices that reduce competitiveness with agricultural crops of interest in the first growing periods, in order to reduce competition for nutrients, light, and especially water. Alternatives such as changes in spacing and density of competing plants can be used to minimize the impact of these species on agricultural crops. 

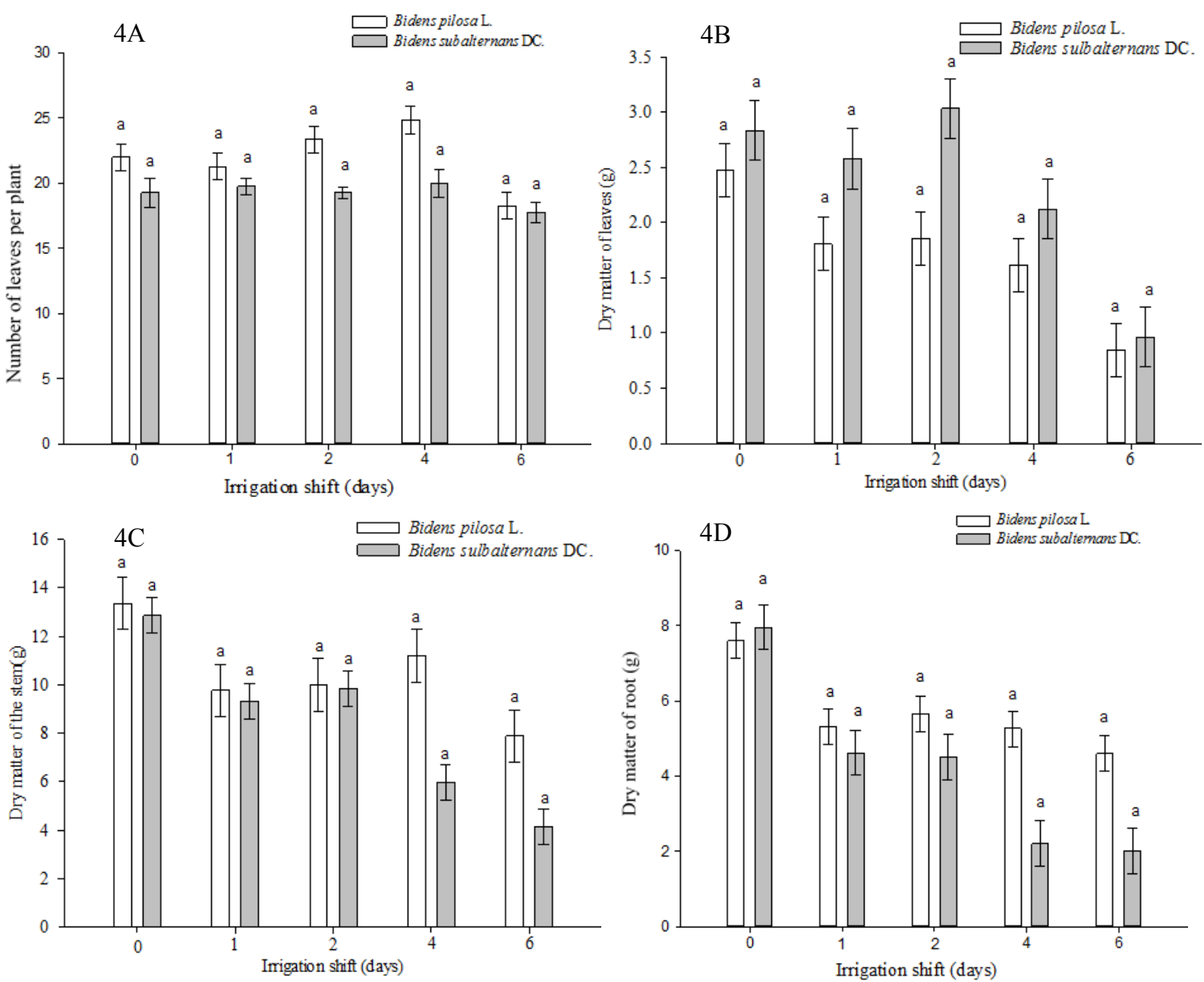

Figure 4. Number of leaves per plant, dry matter of leaves, dry matter of stem, and dry matter of root of Bidens pilosa and Bidens subalternans at 45 days after transplanting and under different irrigation periods. Bars differ the effect of the water deficit in each species by the Tukey test at $p>0.05$. Letters differ the species in each treatment by the Tukey test at $p>$ 0.05 .

\section{CONCLUSIONS}

The results showed that the species B. pilosa and $B$. subalternans can tolerate conditions of low water availability in the soil. The mechanisms involved for this ability may involve factors from the reduction of the stomatal opening to loss of leaves by the plant. However, these mechanisms occur only when soil water availability approaches a value close to $25 \%$ of field capacity. The B. subalternans species showed greater sensitivity as the available soil water was reduced, showing a greater reduction in the dry matter of leaf, stem, and root compared to B. pilosa species.

\section{ACKNOWLEDGEMENTS}

This study was financed in part by the Coordenação de Aperfeiçoamento de Pessoal de Nível Superior - Brasil (CAPES) - Finance Code 001.

\section{REFERENCES}

ASFAW, A. et al. Variability and time series trend analysis of rainfall and temperature in northcentral Ethiopia: A case study in Woleka sub-basin. Weather and Climate Extremes, 19: 29-41, 2018.

CARVALHO, J. S. B.; MARTINS, J. D. L.; MOREIRA, K. A. Respostas fisiológicas de Hyptis pectinata (L.) Poit. ao estresse hídrico. Revista de Biologia e Ciências da Terra, 12: 20-28, 2012.

CAVAlCANTI, F. J. A. Recomendações de adubação para o Estado de Pernambuco. 2. ed. Recife, PE: IPA, 2008, 212 p.

CECHIN, I. et al. Differential responses between mature and young leaves of sunflower plants to oxidative stress caused by water deficit. Revista Ciência Rural, 40: 1290-1294, 2010.

DEISS, L. et al. Weed competition with soybean in no-tillage agroforestry and sole-crop systems in 
subtropical Brazil. Planta Daninha, 35: 1-11, 2017.

DUTRA, A. F. et al. Parâmetros fisiológicos e componentes de produção de feijão-caupi cultivado sob deficiência hídrica. Revista Brasileira de Ciências Agrárias, 10: 189-197, 2015.

FREITAS, C. D. M. et al. Effect of competition on the interaction between maize and weed exposed to water deficiency. Revista Caatinga, 32: 719-729, 2019.

FREITAS, C. D. M. et al. Gaseous exchanges of corn and weeds under competition and water regimes. Revista Brasileira de Engenharia Agrícola e Ambiental, 24: 465-473, 2020.

FREITAS, R. M. O. et al. Physiological responses of cowpea under water stress and rewatering in notillage and conventional tillage systems. Revista Caatinga, 30: 559-567, 2017.

GUENNI, O. et al. Survival strategies of Centrosema molle and $C$. macrocarpum in response to drought. Tropical Grasslands-Forrajes Tropicales, 5: 1-18, 2017.

LEMOS, J. P. et al. Management of Bidens pilosa and Commelina benghalensis in organic corn cultivation under no-tillage. Planta Daninha, 31: 351-357, 2013.

LIMA, M. J. et al. Efeito combinado das variáveis meteorológicas sobre a condutância estomática do feijão-caupi. Horticultura Brasileira, 34: 547-553, 2016.

LLUSIA, J. et al. Photosynthesis, stomatal conductance and terpene emission response to water availability in dry and mesic Mediterranean forests. Trees, 30: 749-759, 2016.

LORENZI, H. Plantas daninhas do Brasil: terrestres, aquáticas, parasitas e tóxicas. 4.ed. Nova Odessa, SP: Plantarum, 2008, 640 p.

MUDO, L. E. D. et al. Leaf gas exchange and flowering of mango sprayed with biostimulant in semi-arid region. Revista Caatinga, 33: 332-340, 2020.

NEGIN, B.; MOSHELION, M. The evolution of the role of $\mathrm{ABA}$ in the regulation of water-use efficiency: From biochemical mechanisms to stomatal conductance. Plant Science, 251: 82-89, 2016.

OTTO, M. S. G. et al. Fotossíntese, condutância estomática e produtividade de clones de Eucalyptus sob diferentes condições edafoclimáticas. Revista Árvore, 37: 431-439, 2013.

PAMPLONA, J. P. et al. Seed germination of Bidens subalternans DC. exposed to different environmental factors. PLoS ONE, 15: 1-12, 2020.

PROCÓPIO, S. O. et al. Análise do crescimento e eficiência no uso da água pelas culturas de soja e do feijão e por plantas daninhas. Acta Scientiarum, 24: 1345-1351, 2002.

PROCÓPIO, S. O. et al. Características fisiológicas das culturas de soja e feijão e de três espécies de plantas daninhas. Planta Daninha, 22: 211-216, 2004a.

PROCÓPIO, S. O. et al. Ponto de murcha permanente de soja, feijão e plantas daninhas. Planta Daninha, 22: 35-41, 2004b.

RAFAIN, E. F. et al. Correlation between sowing and fertilizer application systems and weeds in soybean crops. Revista Caatinga, 33: 281-286, 2020 .

RAMESH, K. et al. Weeds in a changing climate: vulnerabilities, consequences, and implications for future weed management. Frontiers in Plant Science, 8: 1-12, 2017.

SANTOS, A. S. et al. Influence of Uroclhoa brizantha cv. Marandu phytomass in the control of Bidens subalternans under dystrophic yellow latossol. African Journal of Agricultural Research, 10: 4215-4221, 2015.

SILVA, F. L. et al. Compilation of secondary metabolites from Bidens pilosa L. Molecules, 16: 1070-1102, 2011.

SOARES, M. M. et al. Effects of competition and water deficiency on sunflower and weed growth. Revista Caatinga, 32: 318-328, 2019.

SOUZA, M. F. et al. Soil water availability alter the weed community and its interference on onion crops. Scientiae Horticulturae, 272: 1-10, 2020.

SPINELLI, G. M. et al. Water stress causes stomatal closure but does not reduce canopy evapotranspiration in almond. Agricultural Water Management, 168: 11-22, 2016.

STEADMAN, K. J. et al. Maturation temperature and rainfall influence seed dormancy characteristics of annual ryegrass (Lolium rigidum). Australian Journal of Agricultural Research, 55: 1047-1057, 2004. 
TAIZ, L. et al. Fisiologia e desenvolvimento vegetal. 6. ed. Porto Alegre, RS: Artmed, 2017, 888 p.

TOMBESI, S. et al. Stomatal closure is induced by hydraulic signals and maintained by ABA in drought -stressed grapevine. Nature Scientific reports, 5: 1$12,2015$.

WEN, B. et al. Seed germination of the invasive species Piper aduncum as influenced by high temperature and water stress. Weed Research, 55: 155-162, 2015. 